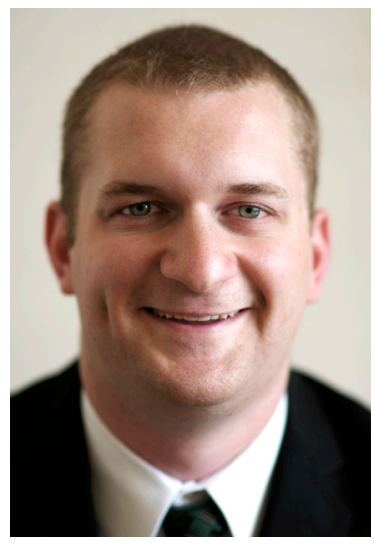

ANDREW ENGDAHL is currently pursuing a Bachelor of Arts in History as well as a Bachelor of Science in Business Administration/ Marketing at Cal Poly, San Luis Obispo. His academic interests lie in the study of Pre-Industrial World History, specifically with regard to the Middle Ages and Early Modern Europe. He is also an Eagle Scout, a graduate of the Orfalea College of Business' Leadership Program, and an active member of Cal Poly's Alpha Nu Gamma Chapter of the National History Honor Society, Phi Alpha Theta. Andrew's hobbies include traveling, rock-climbing, dancing, reading, and surfing, and will be studying abroad in the 2012 Cal Poly in Spain-Summer Program. Andrew is currently employed as a History/Writing tutor for Cal Poly Athletics as well as a Teaching Assistant in the Cal Poly History Department, and upon graduating from Cal Poly he plans to pursue a Ph.D in History and become a college professor. 


\title{
A CURIOUS ELIXIR: MEDICINAL BEER IN THE AGE OF PROHIBITION
}

\author{
Andrew Engdahl
}

Though it may be seen as outlandish by modern medical standards, alcoholic beverages were widely prescribed as a form of medicine prior to the advent of Prohibition in the United States. ${ }^{1}$ In fact, "medicinal beer," specifically, was so widely accepted for its importance as a therapeutic agent that the question of its viability caused a determined group of American physicians to launch a legislative battle that had a lasting impact on the domestic politics of the United States in the early 1920s. Although The New York Times covered this debate extensively from 1909 to 1922, the movement for medicinal beer has largely remained a historical enigma of the early twentieth century.

Thus far, most of the scholarly discussion of Prohibition has tended to focus more generally on subjects such as bathtub gin, the American flapper

\footnotetext{
${ }^{1}$ Lewis Shapter, "The Use Of Alcohol In Relation To Public Health," The British Medical Journal 2, no. 1071 (Jul. 9, 1881): 44-46; "Convenient Diet-Lists for Private Duty Nurses," The American Journal of Nursing 1, no. 2 (Nov. 1900): 119-129; E.C. Hamill, "The Fort Bayard Hospital for Tuberculosis," The American Journal of Nursing 18, no. 8 (May 1918): 665-667; A.S. Blumgarten, "The Administration of Medicines (Continued)," The American Journal of Nursing 15, no. 4 (Jan. 1915): 285-290; A.S. Blumgarten, "The Administration of Medicines (Continued)," The American Journal of Nursing 15, no. 7 (Apr. 1915): 565-572.
} 
girl, the swinging speakeasy, and the infamous life and crimes of Al Capone. ${ }^{2}$ Furthermore, the overwhelming majority of historians that have addressed the subject of beer in relation to Prohibition have predominantly focused their discussions on the development of the Women's Christian Temperance Movement, the rise of the Anti-Saloon League, and the general trials and tribulations of major American breweries like Anheuser-Busch, Coors, and Pabst. ${ }^{3}$ Be that as it may, there have been a select few scholars that have touched upon the subject of the medicinal beer debate in their writings, but only to a certain extent. Dr. Charles Bamforth, the Chair of the Department of Food Science at the University of California, Davis, provides a reasonable glimpse of the movement for medicinal beer by noting that the campaign for "medicinal beer" arose in 1921 when a group of brewers and physicians lobbied the government for the right to produce and distribute beer as medicine. ${ }^{4}$ However, Bamforth provides very little information on the subject beyond the most basic of details. Furthermore, his writings also lack statistical figures that would provide a sense of scope for how many physicians actually did perceive beer to be a viable medicinal supplement. ${ }^{5}$ Likewise, Dr. Stephanie Pain, the associate editor of the peer-reviewed journal New Scientist, and Beverly Gage, an associate

${ }^{2}$ Terry Ganey and Peter Hernon, Under the Influence: The Unauthorized Story of the Anheuser Busch Dynasty (New York: Simon \& Shuster, 1991); Mark Abridge and Swarna Weerasinghe, "Homicide in Chicago from 1890 to 1930: Prohibition and its Impact on Alcohol- and NonAlcohol-Related Homicides" Addiction 104, no. 3 (March 2009): 355-364; Jack S. Blocker Jr., “Did Prohibition Really Work?” American Journal of Public Health 96, no. 2 (Feb. 2006): 233-243; Melissa Burdick Harmon, "The Life and Crimes of Al Capone" Biography 5, no. 5 (May 2001): 100; Seth Kugel, "Speakeasies: Tell Them Seth Sent You," The New York Times, April 29, 2007; "Feb. 14 1929: The St. Valentine's Day Massacre in Chicago," History Today 59, no. 2 (Feb. 2009): 10; Charles Bamforth, Grape vs. Grain: A Historical, Technological, and Social Comparison of Wine and Beer (New York: Cambridge University Press, 2008).

${ }^{3}$ Philip Van Munching, Beer Blast: The Inside Story of the Brewing Industry's Bizarre Battles for Your Money (New York: Random House, 1997); Ronald Jan Plavchan, A History of Anheuser-Busch 1852-1933 (New York: Arno Press, 1976); Tom Goyens, Beer and Revolution: The German Anarchist Movement in New York City, 1880-1914 (Urbana and Chicago: University of Illinois Press, 2007); Terry Ganey and Peter Hernon, Under the Influence: The Unauthorized Story of the Anheuser Busch Dynasty (New York: Simon \& Shuster, 1991); William L. Downard, The Cincinnati Brewing Industry (Athens: Ohio University Press, 1973); Thomas C. Cochran, The Pabst Brewing Company: The History of an American Business (1948; repr. Westport: Greenwood Press, 1975); Blocker, 233-243; Dan Baum, Citizen Coors: An American Dynasty (New York: HarperCollins Publishers Inc., 2000); Stanley Baron, Brewed in America (Boston: Little, Brown and Company, 1962).

${ }^{4}$ Bamforth.

${ }^{5}$ Ibid. 
professor of history at Yale University, each have written articles that address the motivations of the doctors that pushed the movement for medicinal beer, but do not elaborate extensively upon the movement's overall impact on U.S. Prohibition as a whole. ${ }^{6}$ Although I agree with the majority of the claims that are made by these scholars, I feel that there is much more to be said about the medicinal beer movement than has been presented thus far. With that in mind I intend to further illuminate this historical enigma so that it may be more appropriately recognized as an important element of the early Prohibition years.

I aim to argue that the debate over the validity of this curious elixir led several American doctors to join together to form the first solid legislative resistance movement to the restrictions of the Eighteenth Amendment. This paper will initially explore the traditional uses of medicinal beer in the late 1800s, the debate over the therapeutic merits of beer within the medical community at the turn of the century, and the various internal and external factors that influenced the rise of the movement. Furthermore, I will illustrate the major elements of the medicinal beer movement after the passing of the Eighteenth Amendment, discuss the motivations and actions of the major supporters and opponents of the movement, and ultimately elaborate on how the movement failed to re-legalize beer with the passing of the Willis-Campbell Law. Although these obstinate physicians stood together in the name of beer, the focus of their ire did not revolve around the questionable therapeutic benefits of the dubious brew alone; in the eyes of the medical community, the government had overstepped its bounds by trying to control what a physician could determine to be medicine.

Although beer has long been viewed as a recreational beverage, it was widely perceived to be a relatively versatile medicinal agent toward the end of the nineteenth century. For example, according to Frederick William Salem, an ardent beer activist of the 1880s, the U.S. Department of Agriculture published a report in 1866 that stated that "moderate use of pure beer [would] aid digestion, quicken the powers of life, and give elasticity to the body and mind."

\footnotetext{
${ }^{6}$ Beverly Gage, "Just What the Doctor Ordered” Smithsonian 36, no. 1 (April 2005): 112-117; Stephanie Pain, "The Battle for Medicinal Beer" New Scientist 199, no. 2680 (Nov. 2, 2008): 44-45; "Scientists in Journalism: A Profile of Stephanie Pain, Associate Director of New Scientist" Nature 402, no. 6758 (Nov. 11, 1999): 13; Yale History Department, "Beverly Gage, Associate Professor" Yale University, http://www.yale.edu/history/faculty/gage_b.html (accessed May 8, 2011).

${ }^{7}$ Frederick William Salem, Beer, Its History and Its Economic Value as a National Beverage (1880; repr. New York: Arno Press, 1972); Shapter, 44-46.
} 
This position received further support in 1881 when The British Medical Journal printed an article that praised the merits of alcoholic beverages like beer for their merits as nutritious stimulants. ${ }^{8}$ By the early 1900s, the perceived medicinal benefits of beer had grown so extensive that it became widely accepted as a viable therapeutic agent in the treatment of typhoid fever, constipation, diabetes, staph infection, and tuberculosis. ${ }^{9}$ Lastly, medical professionals praised beer as a useful solvent in the administration of other drugs because they believed that it could effectively slow the absorption rate of hypnotic drugs to maximize the duration of their effects. ${ }^{10}$ From a modern perspective these supposed medicinal qualities of beer might seem laughable, however, it is important to note that advancements in the field of medicine at the turn of the century led many doctors to reevaluate just how effective their malty remedy really was. ${ }^{11}$

In the early 1900s, it became obvious that professional opinions of the therapeutic merits of medicinal beer began to shift, as the debate over the subject within the medical community soon rose to national prominence. According to a New York Times article from 1909, some medical students contended that alcohol had no therapeutic benefits at all, and even if it did, its use in the medical field had diminished significantly. ${ }^{12}$ By 1917 , the viability of alcohol was called into question further by Dr. Haven Emerson, the Health Commissioner of New York City, who had correctly identified alcohol to be a depressant that caused "damage to the heart, kidneys and blood vessels, as well as to the stomach and liver." ${ }^{13}$ In response to these comments, Dr. Abraham Jacobi, an ardent advocate of the medicinal benefits of alcohol, contended that alcoholic beverages still remained "valuable" and "indispensible" as traditional remedies, and that the "prohibition movement kept up by ' 400,000 ' women [was] no

${ }^{8}$ Shapter, $44-46$.

9 "Convenient Diet-Lists for Private Duty Nurses," 119-129; Hamill, 665-667; "Reports And Analyses And Descriptions Of New Inventions, In Medicine, Surgery, Dietetics, And The Allied Sciences," The British Medical Journal 1, no. 2161 (May 31, 1902): 1342-1343; Shapter, 44-46.

${ }^{10}$ Blumgarten, "The Administration of Medicines (Continued)," (Jan. 1915): 285-290; Blumgarten, "The Administration of Medicines (Continued)" (Apr. 1915): 565-572; "Reports And Analyses And Descriptions Of New Inventions, In Medicine, Surgery, Dietetics, And The Allied Sciences," 1342-1343.

11 "Value of Alcohol in Medicine Small." The New York Times, March 18, 1909; "Medical Science on the Side of Alcohol." The New York Times, Sept. 2, 1917; "Prohibition And The Medical Profession,” The British Medical Journal 1, no. 3194 (Mar. 18, 1922.): 448.

12 "Value of Alcohol in Medicine Small."

13 "Medical Science on the Side of Alcohol." The New York Times, Sept. 2, 1917. 
proof" that alcohol had lost its edge as a mainstream medicine. ${ }^{14}$ In retrospect, the decline in the use of beer in medicine can perhaps be best explained by the fact that advancements in the medical field began to show that beer was simply not as effective in treating disease as it had once been thought. However, as Dr. Jacobi made abundantly clear, the influence that the Prohibitionist movement wielded over the debate cannot be ignored.

By the time the debate over the validity of beer had risen to national prominence, support of Prohibition in U.S. politics had grown substantially. In the late 1800s and early 1900s, organizations, such as the Women's Christian Temperance Movement and the Anti-Saloon League campaigned heavily to rid the country of alcoholic beverages in every capacity, and this increasingly popular sentiment likely had an impact on how some doctors handled their treatment of medicinal alcohol. ${ }^{15}$ Prohibitionists wanted to use any information they could to have alcohol outlawed, and the growing doubts about the therapeutic benefits of beer within the medical community likely served beneficial to their cause. Regardless of whether or not these temperate sentiments held any sway over the medical community at large, the Prohibitionists ultimately succeeded in rendering alcohol illegal through the passing of the Eighteenth Amendment on January 16, 1919. Shortly afterward, Congress also passed the Volstead Act, which served as the Eighteenth Amendment's bill of enforcement in that it levied harsh penalties for the production, sale, and transport of beverages that exceeded $0.5 \%$ in alcohol content. ${ }^{16}$ The passing of the Eighteenth Amendment and Volstead Act caused the debate within the medical profession to shift sharply from being a question of whether or not beer was truly a viable medicine to being a question of what the government had the right to regulate within in the medical field.

On March 18, 1922, The British Medical Journal published an article titled "Prohibition and the Medical Profession." ${ }^{17}$ Summarizing the results of a survey distributed among 53,000 medical practitioners in the United States by the Journal of the American Medical Association, the article was meant to objectively

${ }^{14}$ Ibid.

${ }^{15}$ Munching; Plavchan; Goyens; Ganey and Hernon; Downard; Cochran; Blocker, 233-243; Baum; Baron.

${ }^{16}$ Downard, Dictionary of the History of the American Brewing and Distilling Industries (Westport: Greenwood Press, 1980).

17 "Prohibition And The Medical Profession," 448. 
frame the state of opinions within the American medical community over the viability of medicinal alcoholic beverages. One of the central elements of the discussion revolved around the relevance of medicinal beer in the contemporary treatment of patients. Of the original 53,000 U.S. medical practitioners that had been asked to participate in the study (37\% percent of all physicians working within the U.S. at the time), 31,115 chose to offer their responses. It is unclear why 21,885 physicians chose not to participate in the study, but any number of reasons could have contributed to this statistic. Laziness or indifference on the part of some of the physicians could have influenced these results, but such assertions are purely speculative. Regardless, assuming that these figures were accurate, one can infer that this statistical sample had captured the opinions of nearly 22 percent of the approximate 143,243 doctors that were in active practice in the United States at the time. ${ }^{18}$ Based on these numbers alone, there is no question that the subject of Prohibition was a hot topic for debate within the medical profession because over one-fifth of all physicians in the United States had decided to weigh in on the issue.

Overall, the Journal of the American Medical Association's survey findings yielded peculiar results. On the question of whiskey as being a necessary medicinal agent, the survey had generated a nearly even distribution of professional opinions, in which 51 percent of the respondents found its effects valuable and 49 percent did not. When posed with the same question with regard to wine, just 32 percent considered it a viable medicine while 68 percent did not. However, perhaps the most surprising response of all was the fact that, of the doctors surveyed, only 26 percent of them found beer to be a viable medicine. ${ }^{19}$ Dr. Stephanie Pain referenced these survey results in her essay titled "The Battle for Medicinal Beer," but she limited her discussion solely to the statistics on medicinal whiskey. ${ }^{20}$ What needs to be emphasized here is that the overwhelming majority of physicians in the United States (approximately $74 \%$ of them) did not feel that beer was a viable medicinal supplement when compared to whiskey and wine. Although it was apparent that the use of medicinal beer was on the decline, it is important to note that a sizeable minority of physicians still valued the beverage as a therapeutic agent. When framed in this context, it

\footnotetext{
${ }^{18}$ Ibid.

${ }^{19}$ Ibid.

${ }^{20}$ Pain, 44-45.
} 
becomes readily apparent that a consensus was shared by many doctors during the period that the government had no place in trying to control what they and their colleagues could determine to be viable medicinal treatments. Regardless of whether they were advocates or skeptics of the viability of medicinal beer, many physicians believed that, as a result of their education and years of training in the medical field, the responsibility of what a doctor could prescribe as medicine should have been up to the discretion of the doctor, and him alone. As such, many within the American Medical Association chose to fight for their right to prescribe medicinal beer as a matter of principle. ${ }^{21}$

After a great deal of public debate and lobbying, the medical profession finally won a small victory for itself when Attorney General A. Mitchell Palmer issued a ruling that rendered medicinal beer exempt from the constraints of the Volstead Act on March 3, 1921.22 Palmer ruled that the Internal Revenue Bureau did not have the power to limit the number of permits that it could distribute for the manufacture and sale of medicinal beers and wines, with the only stipulation being that only reputable brewers would be eligible to apply for the permits. ${ }^{23}$ Though Palmer had long been a strong advocate of Prohibition, his decision to loosen the regulations on the production and distribution of medicinal beer had essentially rendered it legal. Although it is unclear exactly why Attorney General Palmer chose to make this surprising turnaround, there are a couple of plausible explanations. Beverly Gage noted that his motivations likely lied in the fact that Palmer had been under a considerable amount of pressure from what remained of the U.S. brewing industry. When coupled with the fact that the Attorney General was only days away from being replaced, as Warren G. Harding had just been elected to the presidency of the United States, it is entirely possible that Palmer's imminent replacement may have influenced his decision to shake up the political environment for his successor. However, one can never know for certain and this is likely the result of speculation on Gage's part. ${ }^{24}$ Needless to say, Palmer's decision to accept a doctor's right to prescribe medicinal beer had left the Prohibitionist organizations feeling bewildered and threatened. The Anti-Saloon League, specifically, became so incensed

\footnotetext{
${ }^{21}$ Anti-Beer Bill." The New York Times, Nov. 21, 1921.

${ }^{22}$ Pain, 44-45; Bamforth; Gage, 112-117; "Medical Beer," The New York Times, March 12, 1921.

${ }^{23}$ Ibid.

${ }^{24}$ Gage, 112-117.
} 
with the success of the medicinal beer campaign that they filed an appeal to the Department of Justice against the Treasury's ruling. ${ }^{25}$

Given the circumstances of this situation, it is easy to understand the frustration that was felt by the Prohibitionists at the time. Since it had been established in 1893, the Anti-Saloon League had worked tirelessly to break the spirit of the American saloon and to bring about the complete and total ban of alcohol in the United States. ${ }^{26}$ With this one decision by the Attorney General, the organization came to feel that the "booze-free" America that they had spent nearly three decades trying to build had been undermined. The members of the Anti-Saloon League knew that the American Medical Association's motivations did not lie simply in the endorsement of beer's supposed medicinal benefits. The Anti-Saloon League recognized that there was more to the medicinal beer campaign than met the eye, and they stood resolute in the assumption that the entire movement served as a front for American doctors to use their strategic position in the medical field as a loophole with which they could take advantage of reintroducing recreational alcohol to the general public. ${ }^{27}$ Though there may be some truth to these negative sentiments, it is important to note that though a minority of a mere 26 percent, over a quarter all physicians within the U.S. at the time still found beer to be a vital and entirely necessary medicine. ${ }^{28}$ There may very well have been a handful of corrupt doctors that wanted to take advantage of the medicinal beer movement for the sake of personal gain, but I would argue that it is more likely the case that the majority of doctors that stood for medicinal beer did so because they supported the right of their colleagues to practice medicine as they thought best for their patients. ${ }^{29}$ However, regardless of the true motivations of the advocates of medicinal beer, Attorney General Palmer's decision to allow reputable brewers and doctors to produce and prescribe medicinal beer went into full swing in the later months of 1921 .

Immediately following Attorney General Palmer's decision to allow physicians to prescribe medicinal beer a mere eight months earlier, the Internal Revenue Bureau began to institute a sweeping set of new regulations on October

25 "Medical Beer."

${ }^{26}$ Downard.

27 "Medical Beer"; Pain, 44-45; Gage, 112-117.

28 "Prohibition And The Medical Profession," 448.

${ }^{29}$ Pain, 44-45; "Prohibition And The Medical Profession," 448; "Physicians Ask Veto of AntiBeer Bill.” 
24, 1921 that began to lay the framework with which medicinal beer was to operate within the confines of Prohibition regulations. Among these new regulations were stipulations that held doctors to a standard in which they could not write prescriptions for themselves nor prescribe more than one pint of beer per patient in a ten-day period. ${ }^{30}$ Furthermore the privileges for the production and sale of medicinal beer were only extended to nine states: California, Connecticut, Massachusetts, Missouri, New Jersey, New York, Pennsylvania, Rhode Island, and Wisconsin. ${ }^{31}$ Lastly, the breweries within these states were required to obtain permits before they were able to begin to produce beer for medicinal consumption. Any brewery that had openly produced beer after the Eighteenth Amendment became the law of the land remained ineligible for these permits once they became available. ${ }^{32}$

However, regardless of these circumstances, the Prohibitionists only viewed these regulatory measures as temporary concessions to the medical and brewing industries as they endeavored to revise the provisions of the Eighteenth Amendment so that medicinal beer could be rendered illegal once more. ${ }^{33}$ The "dry" faction within the United States at the time had felt that the push for medicinal beer had "outraged" the Volstead Act and the Eighteenth Amendment by rendering druggists as the new "bartenders," drug stores as the new "saloons," and doctors as "beer dictators" that would only serve people who wanted to drink. ${ }^{34}$ By late November of 1921, Congressman Andrew Volstead and Wayne B. Wheeler, the author of the Volstead Act and the national counsel of the Anti-Saloon League, respectively, succeeded in their goal of passing the WillisCampbell Law through Congress. This new legislation effectively rendered medicinal beer to be illegal in every capacity, while wine and whiskey were deemed to be viable medicinal supplements that could only be prescribed in quantities of less than half a pint per ten-day period. ${ }^{35}$ This development is notable because the Prohibitionists had allowed themselves to come to the same conclusions about wine and whiskey as the wide majority of medical professionals at the time. Both physicians and Prohibitionists alike considered

\footnotetext{
30 "Beer as Medicine 2.5 Gallons at a Time," The New York Times, Oct 25, 1921.

31 "Only 9 States Get Beer as Medicine," The New York Times, Oct. 26, 1921.

32 "Ready to Give Permits to Make Medical Beer," The New York Times, Oct. 27, 1921.

${ }^{33}$ Ibid.

34 "Beer Stein for Sick," The New York Times, Nov. 13, 1921.

35 "Only 9 States Get Beer as Medicine”; “Medical Beer”; Pain, 44-45; Gage, 112-117; Bamforth.
} 
the two substances to be far superior to beer in seemingly every way in terms of their therapeutic effectiveness. ${ }^{36}$ However, despite this new consensus, there was still a portion of the medical community that felt that government had betrayed them by passing the new law. ${ }^{37}$ As such, when the Willis-Campbell Law passed, some physicians continued to lobby the government in the hopes that medicinal beer would be granted a reprieve.

Following the leadership of Dr. John P. Davin, the Executive Secretary of the New York Medical Association, the doctors of the New York Medical Association petitioned President Harding to veto the Willis-Campbell Law immediately after the bill passed. ${ }^{38}$ However, when these fervent requests fell upon deaf ears, a last stand on the subject was made not by a coalition physicians, but by a brewery lawyer. On December 31, 1921, William M.K. Olcott, an attorney to a couple of brewers known as the Piel Brothers, argued on behalf of both physicians and the brewing industry alike before the Federal Court of Brooklyn that the Willis-Campbell Law stood in violation of the Constitution. He made his case on the grounds that the law had invaded upon the personal rights of physicians to be able to prescribe what they deemed fit in the treatment of their patients, and was thus unconstitutional in nature. ${ }^{39}$ Furthermore, Olcott contended that the law had interfered with human rights because it destroyed the right of breweries to cooperate with the medical field, and that the government had overstepped its bounds by usurping police powers that it had never been given before to interfere with the power and authority of the states. ${ }^{40}$ Although Olcott made a valiant effort on the part of the brewing industry, he ultimately failed to convince the government to grant beer medicinal status, thus ending the medicinal beer movement and rendering the manufacture and consumption of beer illegal until Prohibition was eventually repealed eleven years later. ${ }^{41}$

Though only a small facet of the historical monolith that is the subject of U.S. Prohibition, the narrative of the medicinal beer movement provides a fascinating perspective of the history of the early 1920s. The advent of Prohibition

36 "Prohibition And The Medical Profession," 448; Pain, 44-45; Gage, 112-117; Bamforth.

${ }^{37}$ Pain, 44-45; "Prohibition And The Medical Profession," 448; "Physicians Ask Veto of AntiBeer Bill."

38 "Physicians Ask Veto of Anti-Beer Bill."

39 "Olcott Attacks Medical Beer Ban." The New York Times, Jan. 1, 1922.

${ }^{40}$ Ibid.

${ }^{41}$ Bamforth; "Olcott Attacks Medical Beer Ban." 
in the United States led many determined doctors to campaign for their right to prescribe beer to their patients. Though not all within the medical profession agreed upon the viability of beer as a medicinal agent, many supported the medicinal beer movement because they believed that the government had overstepped its bounds by putting restrictions on what a doctor could prescribe as medicine. Conversely, Prohibitionist organizations like the Anti-Saloon league believed that the advocates of medicinal beer secretly harbored ulterior motives in pursuit of their beer-lauding agenda. The Prohibitionists believed that by granting beer official legal status as "medicine," doctors would be able use their professional influence as a means with which they could reintroduce the recreational consumption of beer to the general public. As such, the Anti-Saloon League fought incessantly to put the debate to rest and discredit the therapeutic effectiveness of the curious elixir once and for all. However, regardless of the suspicions of the movement's critics, the campaign for medicinal beer served to show that not all American citizens were happy with the changes that had been implemented by the Eighteenth Amendment. Although the movement ultimately failed, it still served as the first solid legislative resistance movement to the constraints of Prohibition. Through Attorney General Palmer, physicians and brewers alike had won a brief period of legal status for medicinal beer, but the Prohibitionists were determined to stop them and repealed the ruling. The advocates of medicinal beer took the issue to court and lost, but their struggle had shown the government that they would not readily submit to the federal controls that had been forced upon them. The determined medical professionals that had supported the medicinal beer movement in the early 1920 s did not want to relinquish their right to treat their patients as they sought fit, and though they ultimately failed to get the government to grant beer lasting medicinal status, they refused to go down without putting up a valiant fight. 
Abridge, Mark, and Swarna Weerasinghe. "Homicide in Chicago from 1890 to 1930: Prohibition and its Impact on Alcohol- and Non-Alcohol-Related Homicides." Addiction 104, no. 3 (March 2009): 355-364.

Bamforth, Charles. Grape vs. Grain: A Historical, Technological, and Social Comparison of Wine and Beer. New York: Cambridge University Press, 2008.

Baron, Stanley. Brewed in America. Boston: Little, Brown and Company, 1962.

Baum, Dan. Citizen Coors: An American Dynasty. New York: HarperCollins Publishers Inc., 2000.

“Beer as Medicine 2.5 Gallons at a Time.” The New York Times, Oct 25, 1921.

“Beer Stein for Sick.” The New York Times, Nov. 13, 1921.

Blocker, Jack S. Jr. "Did Prohibition Really Work?” American Journal of Public Health 96, no. 2 (Feb. 2006): 233-243.

Blumgarten, A.S. “The Administration of Medicines (Continued)." The American Journal of Nursing 15, no. 4 (Jan. 1915): 285-290.

_. "The Administration of Medicines (Continued)." The American Journal of Nursing 15, no. 7 (Apr. 1915): 565-572.

“Brewer Calls for Dry Enforcement.” The New York Times, May 13, 1921.

Cochran, Thomas C. The Pabst Brewing Company: The History of an American Business. 1948. Reprint, Westport: Greenwood Press, 1975.

"Convenient Diet-Lists for Private Duty Nurses." The American Journal of Nursing 1, no. 2 (Nov. 1900): 119-129.

“Doctor Speaks for Beer.” The New York Times, June 13, 1919.

Downard, William L. Dictionary of the History of the American Brewing and Distilling Industries. Westport: Greenwood Press, 1980.

—. The Cincinnati Brewing Industry. Athens: Ohio University Press, 1973. 
"Feb. 14 1929: The St. Valentine's Day Massacre in Chicago." History Today 59, no. 2 (Feb. 2009): 10.

"Finds 2.75 Beer Violates the Law." The New York Times, July 25, 1919.

Gage, Beverly. "Just What the Doctor Ordered.” Smithsonian 36, no. 1 (April 2005): 112-117.

Ganey, Terry, and Peter Hernon. Under the Influence: The Unauthorized Story of theAnheuser Busch Dynasty. New York: Simon \& Shuster, 1991.

Goyens, Tom. Beer and Revolution: The German Anarchist Movement in New York City, 1880-1914. Urbana and Chicago: University of Illinois Press, 2007.

Hamill, E.C. “The Fort Bayard Hospital for Tuberculosis.” The American Journal of Nursing 18, no. 8 (May 1918): 665-667.

Harmon, Melissa Burdick. "The Life and Crimes of Al Capone." Biography 5, no. 5 (May 2001): 100.

Kugel, Seth “Speakeasies: Tell Them Seth Sent You.” The New York Times, April 29, 2007.

"Liquor Control or Prohibition." The British Medical Journal 2, no. 3053 (Jul. 5, 1919): 21.

"Medical Beer." The New York Times, March 12, 1921.

"Medical Science on the Side of Alcohol." The New York Times, Sept. 2, 1917.

“Olcott Attacks Medical Beer Ban.” The New York Times, Jan. 1, 1922.

“Only 9 States Get Beer as Medicine.” The New York Times, Oct. 26, 1921.

Pain, Stephanie. “The Battle for Medicinal Beer.” New Scientist 199, no. 2680 (Nov.2, 2008): 44-45.

“Physicians Ask Veto of Anti-Beer Bill.” The New York Times, Nov. 21, 1921.

Plavchan, Ronald Jan. A History of Anheuser-Busch 1852-1933. New York: Arno Press, 1976. 
"Prohibition And The Medical Profession." The British Medical Journal 1, no. 3194 (Mar. 18, 1922): 448 .

“Ready to Give Permits to Make Medical Beer." The New York Times, Oct. 27, 1921.

"Reports And Analyses And Descriptions Of New Inventions, In Medicine, Surgery, Dietetics, And The Allied Sciences." The British Medical Journal 1, no. 2161 (May 31, 1902): 1342-1343.

Salem, Frederick William. Beer, Its History and Its Economic Value as a National Beverage. 1880. Reprint, New York: Arno Press, 1972.

"Scientists in Journalism: A Profile of Stephanie Pain, Associate Director of New Scientist." Nature 402, no. 6758 (Nov. 11, 1999): 13.

“Turn to War Beer as Hot Wave Comes.” The New York Times, July 3, 1919.

"Value of Alcohol in Medicine Small." The New York Times, March 18, 1909.

Van Munching, Philip. Beer Blast: The Inside Story of the Brewing Industry's BizarreBattles for Your Money. New York: Random House, 1997.

Yale History Department. "Beverly Gage, Associate Professor," Yale University. http:// www.yale.edu/history/faculty/gage_b.html (accessed May 8, 2011). 